\title{
Diet of the South American frog Leptodactylus ocellatus (Anura, Leptodactylidae) in Uruguay
}

\author{
Raúl Maneyro할 Daniel E. Naya ${ }^{1}$; Inés da Rosa ${ }^{1}$; Andrés Canavero ${ }^{1} \&$ Arley Camargo ${ }^{1,2}$ \\ 1. Sección Zoología Vertebrados, Facultad de Ciencias, Universidad de la República, Iguá 4225, Montevideo 11400, Uruguay. \\ (rmaneyro@fcien.edu.uy) \\ 2. Department of Biology, University of Richmond, Richmond VA 23173, USA.
}

\begin{abstract}
The diet of Leptodactylus ocellatus (L., 1758) was studied in specimens collected at Maldonado Department (Uruguay), where monthly surveys were made between August 1998 and March 2000. A total of 143 frogs were collected, measured, sexed, and dissected, to assess stomach contents. The anurans were grouped into three age classes and four categories (considering sex and capture date). The trophic amplitude for each age class and sexseason category was quantified using Shannon-Weaver Index, and the trophic niche overlap between ages and categories by using the Pianka Index. Comparisons among treatments were made by $G$-tests. The most important prey items were coleopterans (IRI $=2547$ ), and significant correlations were found between predator and prey sizes. The major differences on diet composition were found between extreme age classes (froglets and adults). Significant differences were also detected between sexes in the cold season but not in the warm season. Any of these changes in diet may be related with the availability of prey.
\end{abstract}

KEYWORDS. Trophic niche, Amphibia, Leptodactylus ocellatus, Uruguay.

\section{INTRODUCTION}

The knowledge and understanding of the paths and processes related to amphibian trophic ecology is of interest not only for herpetologists, but also for ecologists (HIRAI \& MatsuI, 1999). The pivotal role of amphibians in aquatic communities was pointed out by several authors (DUELLMAN \& Trueb, 1994; Stebbins \& Cohen, 1995). The global phenomenon of declining amphibian populations (BlAustein, 1994; McCoy, 1994; AlFoRD \& RichARDS, 1999) elevated these vertebrates to a zoological group of special interest.

The leptodactylids are one of the more widely distributed anuran families in South America, and specially Leptodactylus ocellatus (L., 1758) occupies a wide geographical area, including Brazil, Argentina, Paraguay and Uruguay. An extensive literature has been published about this species mainly because of its complex reproductive behaviour. VAZ-FERREIRA \& GERHAU $(1975,1986)$ described parental care of foam nest and tadpole schools by females. Gallardo (1964) and Cei (1980) gave some data about the adult diet for several Argentinian populations. BASso (1990) provided quali-quantitative information about the diet. The feeding ecology of tadpoles and juveniles was described by LAJMANOVICH $(1994,1996)$ for Argentinian populations, but knowledge on the diet of this species in Uruguay is very scarce. LANGONE (1994) reported some data about systematics, behaviour, reproduction and, based on the diet, he stated that this frog may feed on land or in water. The name of the species, $L$. ocellatus, is here adopted in the sense of LANGONE (1994). Some references on the trophic niche of adults and on cannibalistic events in an Uruguayan population, were given by Achaval \& Olmos (1997).

The objective is to describe the diet of an Uruguayan population of Leptodactylus ocellatus in the wild, analyzing the ontogenetic, intersexual, and seasonal changes that may occur.

\section{MATERIAL AND METHODS}

The field work was conducted at Arroyo Espinas $\left(34^{\circ} 47^{\prime} \mathrm{S}, 55^{\circ} 22^{\prime} \mathrm{W}\right)$, Maldonado, Uruguay, between August 1998 and March 2000. The frogs were obtained with pitfall traps and supplementary specimens were hand collected. These animals were anesthetized in situ with 2-phenoxy-ethanol and immediately fixed in $10 \%$ formalin as suggested by CALDWELL (1996). All specimens were deposited in the Vertebrate Zoology Collection, Facultad de Ciencias, Universidad de la República, Uruguay (ZVCB). In the laboratory, snout-vent length (SVL) and mandibular width (MW) were measured to the nearest $0.1 \mathrm{~mm}$. Specimens were ventrally dissected, and stomach and first portion of the intestine were removed (SCHOENER, 1989). The prey contents were analyzed under a binocular microscope and items were determined to order level. The total length (L) and maximum width (W) of all prey items were measured with an ocular micrometric grid (in mm), and the contents were kept in cans with $10 \%$ formalin. The individual prey volume (in $\mathrm{mm}^{3}$ ) was estimated after Dunham (1983) criteria, under the expression $V=4 / 3 \Pi$ (L/ $2)(\mathrm{W} / 2)^{2}$. The total volume of each stomach (TVS) was calculated as the sum of the volume of all prey items present in a given stomach. The minimum sample size was estimated from the cumulative diet diversity curve using Shannon-Weaver index (SHANNON \& WeAVER, 1949) as suggested by KovÁcs \& ТӧвÖк (1997).

Based on the SVL, frogs were grouped into three age classes: froglets (SVL $<50 \mathrm{~mm}$ ), juveniles $(50<\mathrm{SVL}$ $<75 \mathrm{~mm}$ ) and adults (SVL $>75 \mathrm{~mm}$ ). The TVS data allowed to differentiate two feeding periods: a warm season with high foraging rate (November to February) and a cold season with low foraging activity (March to October). Sex of each individual was determined by examination of gonads. From the season (warm and cold) and sex (males and females) factors, were determined four comparison 
groups.

The trophic diversity was analyzed by standardized Shannon-Weaver index: $\mathrm{J}=\mathrm{H} / \log (\mathrm{n})$, where $\mathrm{H}=-\Sigma\left[\mathrm{p}_{\mathrm{i}} \mathrm{X}\right.$ $\left.\log \left(\mathrm{p}_{\mathrm{i}}\right)\right], \mathrm{p}_{\mathrm{i}}$ is the proportion of the $\mathrm{i}$ resource in the sample, and $\mathrm{n}$ is the total number of different resources.

To describe the importance of each item consumed, the index of relative importance (PINKAs et al., 1971) was calculated as: $\mathrm{IRIt}=(\mathrm{POt}) \mathrm{x}(\mathrm{PIt}+\mathrm{PVt})$, where POt is the percentage of occurrence $(100 \mathrm{x}$ number of stomachs contained $\mathrm{t}$ item / total number of stomachs), PIt is the percentage of individuals (100 x total number of individuals of $\mathrm{t}$ in all stomachs / total number of individuals of all taxa in all stomachs), and PVt is the percentage of volume (100 x total volume of individuals of $t$ in all stomachs / total volume of all taxa in all stomachs).

The dietary overlap among groups (age classes, sex-seasons) was evaluated using the Pianka index (PIANKA, 1973): Ojk $=$ Okj $=\left[\Sigma\left(\mathrm{p}_{\mathrm{ij}} \mathrm{x}_{\mathrm{ik}}\right)\right] /\left(\Sigma \mathrm{p}_{\mathrm{ij}}{ }^{2} \mathrm{x} \mathrm{p}_{\mathrm{ik}}{ }^{2}\right)^{0.5}$, where $\mathrm{p}_{\mathrm{ij}}$ and $\mathrm{p}_{\mathrm{ik}}$ are the proportion of the i resource used by the $\mathrm{j}$ and $\mathrm{k}$ paired categories in each treatment. Changes on diets among groups were evaluated by $G$-tests using IRIs. Regressions between prey length (mean, minimum, and maximum of each prey) and predator size (SVL and MW) were made.

\section{RESULTS}

The minimum sample size was estimated in 115 individuals (fig. 1). From a total of 143 stomachs analyzed, $30(21 \%)$ were empty and $113(79,0 \%)$ presented at least one of the 19 taxa identified (tab. I). The overall mean richness of taxa by stomach was $\bar{x}=2.32(\mathrm{SD}= \pm 2.22)$, reaching a value of $\bar{x}=2.96(\mathrm{SD}= \pm 2.10)$, when empty

Table I. Prey types on the diet of Leptodactylus ocellatus $(\mathrm{n}=113)$ from Arroyo Espinas (Balneario Solís, Maldonado, southeastern Uruguay): $\mathrm{O}$, occurrence; $\% \mathrm{O}$, percentage of ocurrence; $\mathrm{N}$, number of individuals; $\% \mathrm{~N}$, percentage of number of individuals; $\mathrm{V}$, volume in $\mathrm{mm}^{3} ; \% \mathrm{~V}$, percentage of volume; IRI, index of relative importance (IRI), showed for each prey items; f, formicids; nf, not formicids.

\begin{tabular}{lrrrrrrr}
\hline Prey items & $\mathrm{O}$ & $\% \mathrm{O}$ & $\mathrm{N}$ & $\% \mathrm{~N}$ & $\mathrm{~V}$ & $\% \mathrm{~V}$ & \multicolumn{1}{c}{ IRI } \\
\hline Arachnida & & & & & & & \\
$\quad$ Araneae & 51 & 35.66 & 167 & 14.37 & 8653.62 & 8.32 & 809.26 \\
$\quad$ Acari & 16 & 11.19 & 90 & 7.75 & 8.07 & 0.01 & 86.75 \\
$\quad$ Opiliones & 5 & 3.50 & 6 & 0.52 & 1260.73 & 1.21 & 6.04 \\
\hline Insecta & & & & & & & \\
$\quad$ Coleoptera & 76 & 53.15 & 303 & 26.08 & 22730.13 & 21.85 & 2547.20 \\
$\quad$ Orthoptera & 35 & 24.48 & 98 & 8.43 & 32475.64 & 31.22 & 970.56 \\
$\quad$ Hemiptera & 40 & 27.97 & 112 & 9.64 & 10194.91 & 9.80 & 543.76 \\
$\quad$ Hymenoptera (f) & 23 & 16.08 & 134 & 11.53 & 4914.82 & 4.72 & 261.47 \\
& 11 & 7.69 & 11 & 0.95 & 590.98 & 0.57 & 11.65 \\
$\quad$ Diptera & 14 & 9.79 & 32 & 2.75 & 161.17 & 0.15 & 28.48 \\
$\quad$ Lepidoptera & 4 & 2.80 & 4 & 0.34 & 355.82 & 0.34 & 1.92 \\
$\quad$ Odonata & 1 & 0.70 & 3 & 0.26 & 15.20 & 0.01 & 0.19 \\
$\quad$ Dermaptera & 1 & 0.70 & 2 & 0.17 & 85.67 & 0.08 & 0.18 \\
$\quad$ Larvae & 25 & 17.48 & 40 & 3.44 & 7829.25 & 7.53 & 191.77 \\
\hline Collembola & 3 & 2.10 & 26 & 2.24 & 6.94 & 0.01 & 4.71 \\
\hline Chilopoda & 4 & 2.80 & 4 & 0.34 & 128.60 & 0.12 & 1.31 \\
\hline Gastropoda & 2 & 1.40 & 2 & 0.17 & 23.28 & 0.02 & 0.27 \\
\hline Crustacea & & & & & & & \\
$\quad$ Isopoda & 13 & 9.09 & 120 & 10.33 & 10098.40 & 9.71 & 182.14 \\
Amphipoda & 1 & 0.70 & 2 & 0.17 & 62.16 & 0.06 & 0.16 \\
\hline Amphibia & & & & & & & \\
$\quad$ Anura & 3 & 2.10 & 3 & 0.26 & 4424.30 & 4.25 & 9.46 \\
\hline TOTAL & & & 1159 & & 104019.69 & & \\
\hline
\end{tabular}

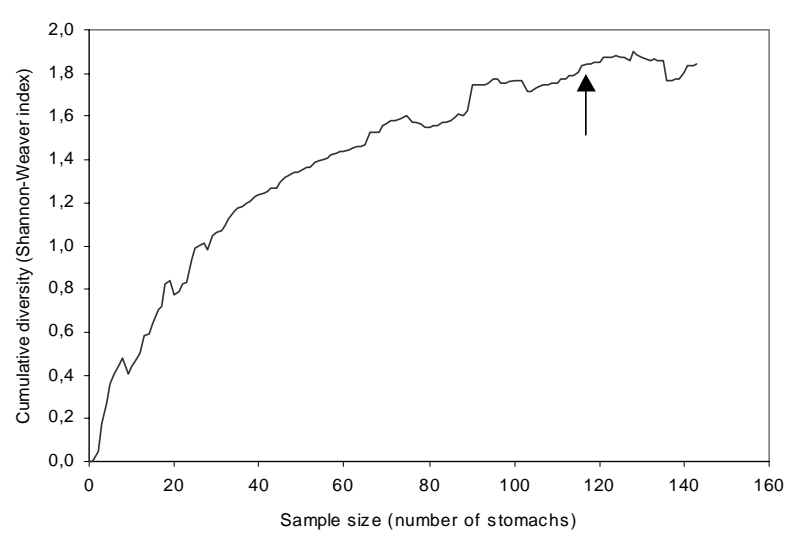

Fig. 1. Cumulative diversity for the overall sample of Leptodactylus ocellatus. Arrow indicates the minimum sample size (115 individuals).

stomachs were not considered. The maximum richness found in a single stomach was 11 items.

The overall diversity (standardized ShannonWeaver index) was $H=0.67$. The total number of prey individuals retrieved was 1159 . The maximum number of prey individuals found in a single stomach was 118 . The mean number of individuals per stomach was $\bar{x}=8.11$ $(\mathrm{SD}= \pm 18.24)$, reaching a value of $\bar{x}=10.35(\mathrm{SD}= \pm$ 20.06), when stomachs without content were not considered.

The index of relative importance showed that the diet of $L$. ocellatus was dominated by coleopterans (IRI =2547.20). Orthopterans (IRI=970.56), spiders (IRI=809.26), hemipterans (543.76), ants (IRI = 261.47), isopods (IRI = 182.14), insect larvae $(I R I=191.77)$, and acari $($ IRI $=86.75)$, were also important taxa in the diet of L. ocellatus (tab. I).

Regressions between prey size (mean, minimum, and maximum prey length in each stomach) and predator length (SVL and MW) were made using all stomachs containing at least one prey individual (tab. II). In five of the six regressions (fig. 2), a positive and statistically significant $(p<0.05)$ slope was found, except for the relationship between minimum prey length and predator SVL, where the slope was also positive but not statistically significant $(\mathrm{p}=0.12)$.

The trophic diversity and the index of relative importance change between age classes for some items

Table II. Regression summary for the variables SVL (snout-vent length) and MW (mandibular width), and maximum (Lmax), average (La) and minimum (Lmin) prey length (values are given in $\mathrm{mm}$ ) of Leptodactylus ocellatus $(\mathrm{n}=113)$ from Arroyo Espinas (Balneario Solís, Maldonado, Uruguay); $\mathrm{p}_{\mathrm{i}}$, intercept probability value; $b$, slope; $p_{b}$, slope probability value; $\mathrm{R}^{2}$, regression coefficient ( $*$, statistically significant values).

\begin{tabular}{clcccc}
\hline & Intercept & $\mathrm{p}_{\mathrm{i}}$ & $\mathrm{B}$ & $\mathrm{p}_{\mathrm{b}}$ & $\mathrm{R}^{2}$ \\
\hline SVL & & & & & \\
Lmax & 1.97 & 0.51 & $0.22^{*}$ & 0.00 & 0.213 \\
La & $3.14^{*}$ & 0.01 & $0.09 *$ & 0.00 & 0.187 \\
Lmin & $2.89 *$ & 0.01 & 0.03 & 0.12 & 0.017 \\
MW & & & & & \\
Lmax & 2.04 & 0.49 & $0.67 *$ & 0.00 & 0.208 \\
La & $2.87 *$ & 0.02 & $0.27 *$ & 0.00 & 0.205 \\
Lmin & $2.47^{*}$ & 0.04 & $0.10^{*}$ & 0.04 & 0.035 \\
\hline
\end{tabular}



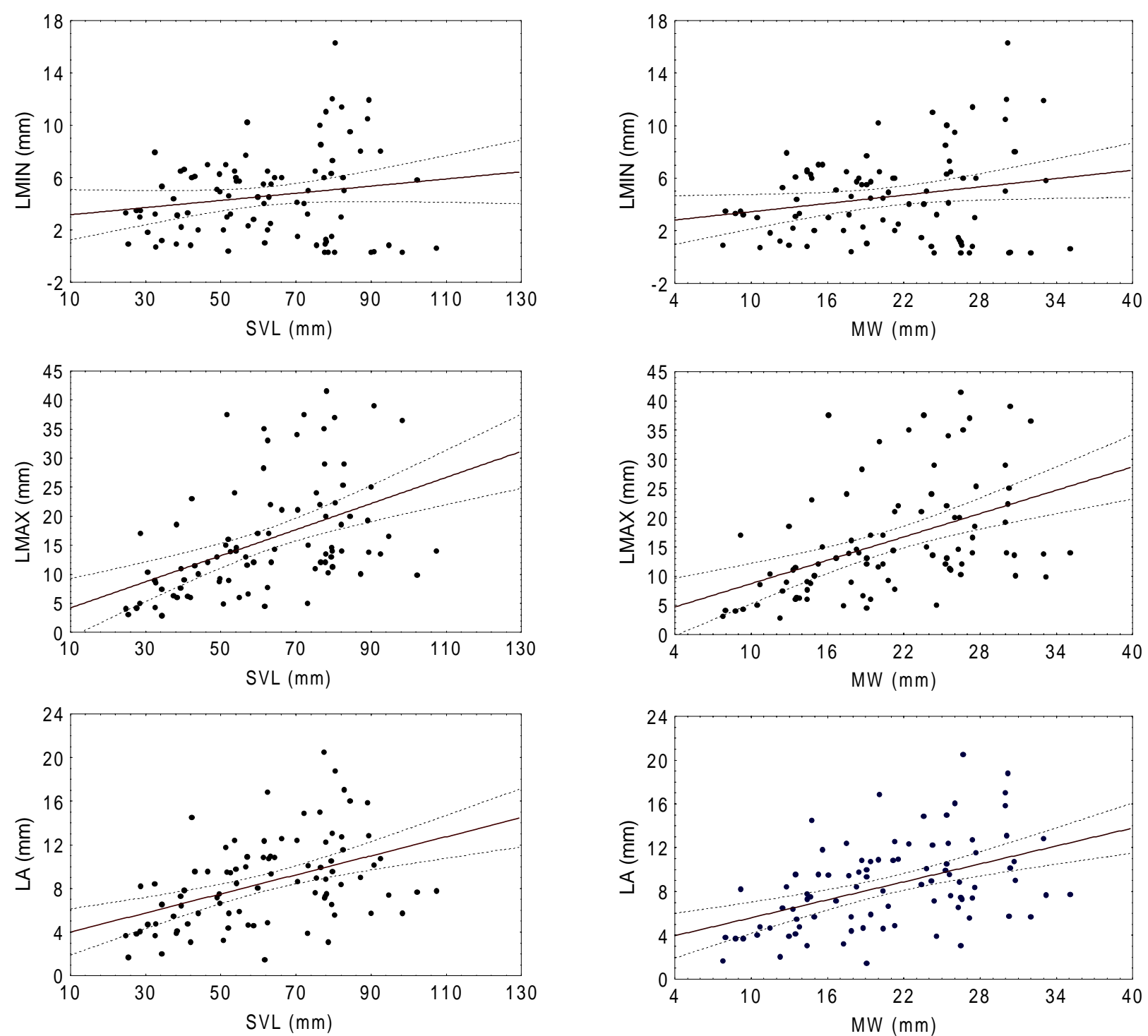

Fig. 2. Regressions between minimum (LMIN), maximum (LMAX) and average (LA) prey length and predator snout-vent lenght (SVL) and mandibular width (MW) of Leptodactylus ocellatus.

Table III. Values of the index of relative importance (IRI) of main prey

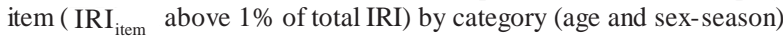
of Leptodactylus ocellatus $(\mathrm{n}=113)$ from Arroyo Espinas (Balneario Solís, Maldonado, Uruguay). Age: F, froglets; J, juveniles; A, adults. Sex-season: MC, males in cold period; MW, males in warm period; FC, females in cold period; FW, females in warm period. $\mathrm{H}$, value of the standarized Shannon-Weaver index for each category. f, formicids. Acari in sex-season classes did not reach IRI values higher than $1 \%$ of total IRI.

\begin{tabular}{lrrrrrrr}
\hline & \multicolumn{3}{c}{ Age classes } & \multicolumn{5}{c}{ Sex - Season classes } \\
\hline & \multicolumn{1}{c}{$\mathrm{F}$} & \multicolumn{1}{c}{$\mathrm{J}$} & \multicolumn{1}{c}{ A } & \multicolumn{1}{c}{ MC } & \multicolumn{1}{c}{ MW } & FC & FW \\
\hline Araneae & 251.66 & 1638.53 & 819.16 & 1226.02 & 875.55 & 731.84 & 2642.74 \\
Acari & 87.29 & 2.06 & 166.35 & & & & \\
Coleoptera & 4137.02 & 3147.62 & 2145.04 & 2521.05 & 4991.31 & 3078.68 & 5445.72 \\
Orthoptera & 634.19 & 1363.79 & 1009.55 & 2397.59 & 473.92 & 1223.61 & 395.68 \\
Hemiptera & 228.34 & 820.61 & 630.66 & 596.12 & 642.24 & 576.53 & 2167.21 \\
Hymenoptera (f) & 55.34 & 64.55 & 568.57 & 575.31 & 79.92 & 204.14 & 627.03 \\
Larvae & 256.74 & 207.88 & 228.27 & 60.23 & 549.81 & 137.43 & 1142.29 \\
Isopoda & 1.00 & 40.44 & 454.63 & 191.77 & 84.87 & 386.31 & 165.46 \\
\hline $\mathrm{H}$ & 0.66 & 0.67 & 0.68 & 0.61 & 0.72 & 0.65 & 0.76 \\
\hline
\end{tabular}

(tab. III). The diet composition showed significant differences among the three age classes $(G=74.2$, df $=$ $14, \mathrm{p}<0.05)$. Differences were significant between the three paired comparisons too. The diet of froglets was more similar to that of the juveniles (Pianka index $=0.876$; $G=21.2$, df $=7, \mathrm{p}<0.05$ ) than to the adult diet (Pianka index $=0.785, G=35.8, \mathrm{df}=7, \mathrm{p}<0.05)$. The trophic niche

Table IV. Niche overlap values (Pianka index) and results of G-tests of Leptodactylus ocellatus $(\mathrm{n}=113)$ from Arroyo Espinas (Balneario Solís, Maldonado, Uruguay) between sex-season categories: MC, males in cold period; MW, males in warm period; FC, females in cold period; FW, females in warm period; $G, G$-test values; df, degrees of freedom; p, $G$ probability value (*, statistically significant values).

\begin{tabular}{lcccl}
\hline & Pianka Index & \multicolumn{1}{c}{$G$} & df & \multicolumn{1}{c}{ P } \\
\hline FC-FW & 0.880 & 19.65 & 7 & $0.006 *$ \\
FC-MC & 0.910 & 19.60 & 7 & $0.006 *$ \\
FW-MW & 0.963 & 4.41 & 7 & 0.731 \\
MC-MW & 0.841 & 25.26 & 7 & $0.000 *$ \\
\hline
\end{tabular}


overlap between juveniles and adults was $0.834(G=45.7$, $\mathrm{df}=7, \mathrm{p}<0.05)$. On taxa level, the isopods were the only group not consumed by froglets.

Some changes have been observed between the four sex-season categories in the trophic diversity and the index of relative importance for each item (tab. III) and the niche overlap (tab. IV). The maximum overlap value was reached by the males in warm season - females in warm season pair (Pianka index $=0.963$ ). In this season (warm), the trophic diversity of each sex is the highest. The diet shows significant differences among the four categories $(G=59.8, \mathrm{df}=21, \mathrm{p}<0.05)$, and between sexseason classes in paired comparisons. The exception was the males in warm season - females in warm season pair, where no significant differences were found $(G=4.41$, $\mathrm{df}=7, \mathrm{p}=0.73)$.

\section{DISCUSSION}

Correlations between the diet of tropical anuran species and environmental variables allowed the classification of these species as generalist or specialist predators (ToFT, 1981). This information is scarce for amphibians from temperate regions (HIRAI \& Matsui, 1999), particularly in South America.

The trophic niche of L. ocellatus in the studied Uruguayan locality would indicate that this frog is nearer to the wide niche predator than to the narrow one, in the continuous specialist-generalist. Characteristics of this kind of frogs (ToFT, 1981) include lower number of prey items and a "sit and wait" foraging mode. The present results agree with those obtained for other leptodactylid frogs, such as Ceratophrys cornuta L., 1758 (DuELlmaN \& LizAnA, 1994), Leptodactylus latinasus Jiménez de la Espada, 1875 (BAsso, 1990) and a species in the $L$. ocellatus group (now L. macrosternum Miranda-Ribeiro, 1926) from Amazonas River basin (STRÜSSMAn et al., 1984).

GALlaRdo (1964) described the diet of L. ocellatus based on 88 specimens, demonstrating that the majority had eaten coleopterans. This prey item has been also found frequently in the diet of a wild population in Argentina (BASso, 1990).

Regressions between frog size (SVL, MW) and prey length showed significant positive correlations. This fact may be interpreted as an ontogenetic change on diet. In the present study, ontogenetic change on diet has been found among three age classes. This kind of change has also been described in some Amazonic leptodactylids by LiMA (1998) and LiMA \& MAGNUSSON (2000). These authors suggested that ontogenetic changes could be explained by prey size and type. LAJMANOVICH (1996) quantified the trophic spectrum of juveniles of L. ocellatus in a wild population at Paraná River, and he found that diet changes with increasing body size. He hypothesized that these changes may be correlated with dispersion mechanisms of the species, since adult frogs move to terrestrial environments with higher prey availability. Our results may partially confirm this hypothesis, because the trophic diversity increases with age classes and the niche overlap (similarity) is greater between neighbour age classes. Some terrestrial prey items, like isopods and ants, increased their value of IRI in a positive way with age class, whereas coleopterans (that include many aquatic taxa) decreased in the value of this index. Spatial changes in prey availability might be discarded because specimens of all age classes were collected in the same localities (traps). A daily segregation may be considered (temporal changes), and may not be excluded as a factor that would explain differences in diet as a response to prey availability.

Sex-seasonal changes have been also detected in the studied population. The occurrence of the high value of overlap index (and not significant differences) between both sexes in the warm season means that both sexes shared a great portion of trophic resources. Significant differences between sexes in the cold season may be interpreted as an "adaptative specialization" related to decreasing of prey availability. These seasonal and intersexual changes may support this hypothesis, because significant fluctuations on dietary composition among classes were detected, with the cold season being the period where the trophic spectrum was lowest. Some authors have suggested this kind of predator responses to prey availability diminishing (JACKSIC, 2001). The dietary plasticity of L. ocellatus may explain, in part, the success of the species in fluctuant environments of temperate regions.

Acknowledgments. To Axel Kwet (Staatliches Museum für Naturkunde Sttutgart), Rafael Lajmanovich (Instituto Nacional de Limnología, CONICET) and William Magnusson (Instituto Nacional de Pesquisas da Amazônia) for the critical review of the manuscript. To Paola Peltzer and Mirco Solé for the language correction. To Matías Arim for statistical help. To Diego Arrieta and José Langone for bibliographic support. To Diego Nuñez, Matilde Alfaro, Leonardo Lorenzo, Mario Clara, and Lucía Ziegler for their help during field work. To Patricia Vaz and Amalia Jauri for logistic help. To Programa de Desarrollo de Ciencias Básicas (PEDECIBA) for partial economical support to RM and DEN.

\section{REFERENCES}

Achaval, F. A. \& Olmos, A. 1997. Anfibios y reptiles del Uruguay. Montevideo, Alejandro Olmos Ed. Barreiro y Ramos S. A. 128p. Serie Fauna, 1.

Alford, R. A. \& Richards, S. J. 1999. Global amphibian declines: a problem in applied ecology. Annual Review of Ecology and Systematics, Palo Alto, 30:133-165.

BAsso, N. 1990. Estrategias adaptativas de una comunidad subtropical de anuros. Monografias Asociación Herpetológica Argentina, San Miguel de Tucumán, 1:1-70.

Blaustein, A. R. 1994. Chicken little or Nero's fiddle? A perspective on declining amphibian populations. Herpetologica, Emporia, 50(1):85-97.

Caldwell, J. P. 1996. The evolution of myrmecophagy and correlates in poison frogs (family Dendrobatidae). Journal of Zoology, London., 240:75-101.

CeI, J. M. 1980. Amphibians of Argentina. Monitore Zoologico Italiano, Nuova Serie, Firenze, 2:1-609.

Duellman, W. E. \& Lizana, M. 1994. Biology of a sit-and-wait predator, the leptodactylid frog Ceratophrys cornuta. Herpetologica, Emporia, 50(1):51-64.

Duellman, W. E. \& Trueb, L. 1994. Biology of amphibians. Baltimore, Johns Hopkins University. 670p.

Dunham, A. E. 1983. Realized niche overlap, resource abundance and intensity of interspecific competition. In: Huey, R. D.; Pianka, E. R. \& Schoener, T. W. eds. Lizard Ecology. London, Harvard University. p.261-280.

Gallardo, J. M. 1964. Anfibios de los alrededores de Buenos Aires. Buenos Aires, Editorial Universitaria de Buenos Aires. $231 \mathrm{p}$. 
Hirai, T. \& Matsui, M. 1999. Feeding habits of the pond frog, Rana nigromaculata, inhabiting rice fields in Kyoto, Japan. Copeia, Lawrence, 1999(4):940-947.

JACKSIC, F. 2001. Ecología de comunidades. Santiago, Universidad Católica de Chile. 233p.

KovÁcs, T. \& TöRÖK, J. 1997. Determination of minimum sample size to estimate diet diversity in anuran species. Herpetological Journal, Huntingdon, 7:43-47.

Lajmanovich, R. 1994. Contribución al conocimiento de la alimentación de larvas de la rana criolla Leptodactylus ocellatus (Amphibia: Anura) en el Paraná, Argentina. Studies on Neotropical Fauna \& Environment, Lisse, 29(1):55-61.

_. 1996. Dinámica trófica de juveniles de Leptodactylus ocellatus (Anura: Leptodactylidae), en una isla del Paraná, Santa Fé, Argentina. Cuadernos de Herpetologia, Tucumán, 10(12):11-23.

Langone, J. A. 1994. Ranas y sapos del Uruguay (reconocimiento y aspectos biológicos). Montevideo, Museo Dámaso Antonio Larrañaga. 123p. (Serie Divulgación, 5)

Lima, A. P. 1998. The effects of size on the diets of six sympatric species of postmetamorphic litter anurans in Central Amazonia. Journal of Herpetology, Glendale, 32(3):392-399.

Lima, A. P. \& Magnusson, W. E. 2000. Does foraging activity change with the ontogeny? An assessment for six sympatric species of postmetamorphic litter anurans in Central Amazonia. Journal of Herpetology, Glendale, 34(2):192-200.

McCoy, E. D. 1994. "Amphibian decline": a scientific dilemma in more ways than one. Herpetologica, Emporia, 50(1):98-103.
Pianka, E. R. 1973. The structure of lizard communities. Annual Review of Ecology and Systematics, Palo Alto, 4:53-74.

Pinkas, L.; Oliphant, M. S. \& Iverson, Z. L. 1971. Food habits of albacore bluefin, tuna and bonito in California waters. California Department of Fish and Game Bulletin, La Jolla, 152:1-350.

Schoener, T. W. 1989. Should hindgut contents be included in lizards dietary compilations? Journal of Herpetology, Glendale, 23:455-458.

Shannon, C. E. \& Weaver, W. 1949. The mathematical theory of communication. Urbana, Illinois University. 117p.

Stebins, R. C. \& Cohen, N. W. 1995. A natural history of amphibians. New Jersey, Princeton University. 316p.

Strüssman, C.; Ribeiro do Vale, M. B. et al. 1984. Diet and foraging mode of Bufo marinus and Leptodactylus ocellatus. Journal of Herpetology, Glendale, 18(2):138-146.

Toғт, C. A. 1981. Feeding ecology of Panamanian litter anurans: patterns in diet and foraging mode. Journal of Herpetology, Glendale, 15(2):139-144.

Vaz-Ferreira, R. \& Gerhau, A. 1975. Comportamiento epimelético de la rana común Leptodactylus ocellatus (L.) (Amphibia, Leptodactylidae) I. Atención de la cría y actividades alimentarias y agresivas relacionadas. Physis, Buenos Aires, 34(88): 1-14.

1986. Comportamiento de los renacuajos gregarios de Leptodactylus ocellatus. Montevideo, Dirección General de Extensión Universitaria, División Publicaciones y Ediciones. $23 \mathrm{p}$ 
